\title{
Actual and Potential Dividends: Reconciling Theory and Practice
}

\author{
Pawel Wnuczak*
}

\begin{abstract}
The concept of potential dividends (PD) and its application in valuation models have been subject to an active debate. The opponents of the inclusion of PD into free cash flow to equity point out the logical inconsistencies and theoretical flaws of the concept, while advocates argue that ignoring the PD in value estimation may cause the results to be biased. I argue that while under rigorous assumptions of the Modigliani-Miller theory the PD concept may appear to be disputable, it represents an important part of the valuation model as soon as those assumptions are relaxed to allow for deviations commonly observed in practice. The aim of the paper is to present guidance to the application of PD and actual dividends (AD) concepts in valuation models. I maintain that each of the two methodologies can be used only in the specifically predefined contexts, which are described in the paper. Ultimately, the paper attempts to make practical recommendations regarding the application of the $\mathrm{PD}$ and $\mathrm{AD}$ concepts in valuation.
\end{abstract}

Keywords: actual cash flow, potential dividends, free cash flow to equity, valuation

\section{Introduction}

The debate regarding the applicability of the PD concept in valuation mostly results in a dichotomy: the opponents (DeAngelo, DeAngelo, 2006; Fernandez, 2002; Velez-Pareja, Magni, 2009) stress the logical inconsistencies inherent in the notion of PD and reject any possibility of its application for valuation purposes, while the advocates (Benninga, Sarig, 1997; Damodaran, 2006) argue that exclusion of PD from valuation leads to an underestimation of the equity value. I make an attempt to prove that this disagreement stems from the fact that each party makes different assumptions regarding the relevance of a dividend payout policy for value management. By addressing the critiques of the PD and AD concepts and analysing the strong and weak points of each methodology, I come up with guidance to its application in valuation models.

According to Modigliani and Miller (1961) the cash flow to equity (CFE) is the difference between dividends paid and net capital contribution, the latter being defined as the difference between equity investments and stock repurchases in the respective period (AD). In turn, the equity market value is defined as:

\footnotetext{
* dr Paweł Wnuczak, Akademia Leona Koźmińskiego w Warszawie, Katedra Finansów, e-mail: pawelw@alk.edu.pl.
} 
where:

$$
E=\sum_{t=1}^{\infty} \frac{(D(t)-I(t))}{(1+\rho)^{t}}
$$

$E$ - equity market value,

$D(t)$ - dividend payment in period $t$,

$I(t)$ - net capital contribution in period $t$,

$\rho-$ cost of equity capital.

As a consequence, the undistributed equity cash flow (i.e., distributable dividends) becomes a part of liquid assets (cash and short-term financial instruments) treated as free cash flow only in the residual period.

Damodaran (1994) proposes another approach to evaluating equity cash flow in which distributable dividends are defined as a part of the available cash flow (PD). As a result, the cash flow to equity is defined as follows:

$$
C F E=X(t)+\operatorname{Depr}(t)-\operatorname{Cap} E x(t)-\Delta W C(t)+\Delta D(t)
$$

where:

$X(t) \quad-$ net income in period $t$,

Depr - depreciation in period $t$,

CapEx - capital expenditure in period $t$,

$\Delta W C(t)$ - change in operating working capital in period $t$, which excludes investments in liquid assets constituting the potential dividends,

$\Delta D(t)$ - change in debt determined as the difference between the net debt issued and debt repaid.

The difference between the two proposed approaches to CFE estimation consists in the treatment of the undistributed equity cash flow. Both approaches yield the same result if the distributable dividends (undistributed liquid assets) in AD approach are assumed to be reinvested at the rate of return equal to the applicable cost of capital (Damodaran, 2006) to the moment of residual period. However, it is commonly argued (Jensen, 1976; DeAngelo, DeAngelo, 2006) that the accumulated cash is being invested at below market rate of return, causing the cash flows to equity calculated according to the PD approach to exceed the cash flows based on actually distributed dividends. The different results yielded by the two approaches prompt the problem of choosing the appropriate methodology to obtain accurate value. Proposing a solution to this dilemma, which is the principal goal of the paper, requires an in-depth analysis of the arguments advanced by the advocates of each of the approaches.

The paper is built in the following way: first, I address the critique of the PD concept, explain why the PD approach should be applied for the purposes of fair value estimation and present the context in which the omission of PD in valuation may cause the model to yield erroneous results; I clarify, why the PD concept, despite being inconsistent with the 
theoretical assumptions of the Modigliani-Miller theory (1961), is generally applicable in practice; I thoroughly analyse the assumptions which condition the choice between the $\mathrm{AD}$ and PD approaches to valuation; afterwards, I introduce a practical guide to the application and interpretation of $\mathrm{PD}$ and $\mathrm{AD}$ in the corporate finance context, recognizing that each methodology is applicable under specific circumstances and under a particular set of assumptions.

\section{Addressing the Critique of the PD Concept}

Velez-Pareja and Magni (2009) argue that the PD concept manifests several theoretical and logical flaws in addition to being in contradiction with the empirical data. From the theoretical standpoint the authors argue that the PD concept: 1) confounds stock and flow, thus, breaking the consistency between cash flow statement and balance sheet; 2) assumes a $100 \%$ pay-out of the present value of liquid assets to stockholders and is inconsistent with the tenets of the MM theory; 3) negates the conclusions of Jensen's theory (1976) implying that due to the agency problem the retained cash is invested at negative NPV; 4) can potentially lead to arbitrage losses for the investor, which recurs to PD methodology.

\section{1. 'The Stock vs. Flow' Argument and the 'Highest and Best Use' Assumption}

To confront the above arguments, I note first, that under the assumption of a strong corporate governance system in place, the stockholder should be treated as a sole proprietor in the sense that ownership entitles the shareholder to the entire free cash flow generated by the company (Damodaran, 2006). This 'strong corporate governance' assumption clarifies why investment into liquid assets despite not being distributed to shareholders, should be included into cash flow to equity. On the one hand, PD represents a stock, on the other hand, unless any restrictions on payout policy apply, the stockholder may claim and force the distribution of the entire distributable cash flow. Thereby, the calculation based on AD, which implicitly relies on the assumption that the retained cash flow will be wasted through investment into projects with negative NPV, would cause the equity value to be significantly underestimated. As noted previously, I make the assumption of the presence of a strong corporate governance system, which is expressed through the application of the 'Highest and Best Use' (HBU) principle endorsed by the International Financial Reporting Standards 13 (IFRS 13) and International Valuation Standards (IVS). HBU, being the necessary prerequisite for the fair value estimation, presumes that managers fulfil their fiduciary duty towards shareholders and use the available assets in the most productive feasible way (Mielcarz, 2014). If this condition is not met, the suboptimal decision making by management will be punished through a takeover or a management replacement (Mielcarz, Wnuczak, 2011).

The dichotomy between stocks and flows for the purpose of value estimation was emphasized by Velez-Pareja and Magni (2009): the authors claim that only AD must be included 
into an equity cash flow calculation since the liquid assets represent a stock and appear on the balance sheet, which constitutes a contradiction with the definition of free cash flow. The logical mistake in this line of reasoning consists in the fact that the undistributed liquid assets constituting a part of PD are not an element of the operational assets. I agree, that PD does not constitute a flow per se, but as noted above, the shareholder is assumed to have a legitimate claim to the entire cash flow generated by the company and may force an additional dividend payout, if the management is suspected of failing to fulfil fiduciary duty towards the stockholders. The eventuality of value destruction through inefficient investments undertaken by the management presumes an asymmetry of information between the managers and the owners, as well as considerable flaws in the system of corporate governance, which deprives the stockholders of opportunities to exercise pressure and shape the investment and dividend payout policies of the company. Such assumptions are in clear contradiction with the HBU principle.

It is claimed as well that the PD concept breaks consistency between the cash flow statement and balance sheet, since according to Velez-Pareja and Magni (2009); all the planned actions (including distribution of the retained cash flow) of the company must be reflected in the forecasted financial statements. It is worth underlying, that a financial projection is based on a set of assumptions which derive from the actual financial statements but are not reflected there. One such fundamental assumption is the unlimited access to zero-NPV projects, which assures that the retained cash flows are value neutral (DeAngelo, DeAngelo, 2006). This assumption represents a simplification of the multitude of investment choices faced by the management, but shows that financial projections do not follow the accounting data.

\subsection{Reinvestment of the Liquid Assets: The 'Zero-NPV' Assumption}

For the AD and PD approaches to yield the same valuation results, the undistributed free cash flow to equity (in practice represented by the accumulated liquid assets) in the AD approach must be reinvested at the rate of return equal to the applicable discount rate. For this to be true there should be opportunities envisaged by the company's management allowing to invest the liquid assets into zero-NPV projects.

Velez-Pareja and Magni (2009) recognize that the zero-NPV assumption may provide a conservative estimate of the equity value, but reject any possibility of investing the liquid assets at the rate equal to the cost of equity capital. It is argued, that the stockpiling of cash causes the destruction of value and constitutes a deviation from rational value-maximizing behaviour.

If we adopt the line of reasoning of Velez-Pareja and Magni (2009), the only rational decision for the shareholders in the case of cash retention by the management would be to force the dividend payout to prevent value destruction. This is not what is commonly observed in practice: companies, especially those experiencing high growth rates (Grullon et al., 2002), 
retain part of the generated cash flows and the owners do not oppose. I propose the following explanation: first, the managers are expected to use the instruments of liquidity management, which, however, cannot generate a rate of return equal to the return on equity; subsequently, management is expected to use the accumulated liquid assets for investment into attractive positive-NPV projects thereby generating value for shareholders. This means, that if the management is envisaging attractive investment opportunities (call options) in future, the value-maximizing strategy consists in retaining part of the generated cash flow and further investing it into a portfolio of positive-NPV projects. However, if the management has exhausted all the value generating investment opportunities, the dividend payout constitutes the strategy in the best interests of the shareholders. Such an explanation is consistent with the HBU principle and constitutes a sound base for the fair value estimate.

To summarize, if we assume that the optimal investment strategy is in place (which may introduce additional distortions into the real-life valuation models), and the company is out of positive-NPV investment projects, we must accept either the payments of dividends or the zero-NPV assumptions for the purpose of fair value estimation which is consistent both with IVS and IFRS 13. On the other hand, if we assume that management is not fulfilling its fiduciary duty towards the shareholders, we cannot assume the optimality of investment policy, which entails the invalidity of the zero-NPV assumption. It should be emphasized that in the majority of such cases the company will eventually be forced to increase the payout under the threat of management replacement.

\subsection{The MM Theory and the PD Concept}

The Modigliani-Miller theory (1961) postulates the irrelevance of financing and dividend payout policies for the company value. The basic tenet on which the theory relies is the optimal investment policy in place which is the only factor influencing the company value directly, while the capital structure and the dividend payout policy only determine the way of repartition of the created value between the sources of financing.

DeAngelo and DeAngelo (2006) stress the fact that the assumptions of MM cause the payout policy decisions to be reduced to the obligatory $100 \%$ payout of the cash flows generated by the company. This entails the irrelevance of the dividend policy for the company value. I agree that under the assumption of the optimality of investment policy, the payout of the entire cash flow is the value-maximizing choice. Allowing for retention under the same assumption causes a deviation from the optimum and may entail the destruction of value. Using this argument DeAngelo and DeAngelo (2006) try to solve the Black's (1976) dividend puzzle, which questions the rationality of dividend payout if the dividends are not in a tax disadvantage relative to capital gains. Clearly, the cash flow retention suggested by Black as a strategy assuring the maximization of shareholders' value would in reality cause the company to destroy value. 
Under the assumptions of MM, the concept of PD is devoid of economic sense as the undistributed equity cash flow cannot appear assuming a $100 \%$ payout of cash flows by the company. As noted by DeAngelo and DeAngelo (2006), the adoption of the MM's postulate regarding the irrelevance of the dividend payout policy entails the conclusion that the dividend payout policy is optimized whenever the optimal investment policy is in place. In other words the MM's assumptions preclude any cash flow retention and force a payout of the entire cash flow. When retention is allowed, the value maximization requires management to make choices both in terms of investment policy and payout policy, the optimal solution being the undertaking of the entire set of positive-NPV projects available to the company and afterwards distributing the entire present value of the generated cash flow (assumed to be reinvested at the rate equal to the applicable cost of capital) over the life of the company. These conclusions in no way contradict the use of the PD concept in valuation models.

Velez-Pareja and Magni (2009) argue that the assumption of the complete distribution of the present value of distributable cash flow to shareholders is flawed, and that analysts should not by default expect the cash flows to be ever distributed unless the management explicitly expresses the intention to do so. I claim, that the company which is 'a going concern' and which never pays dividends, is a theoretical construct, the equity value of such a company would be zero. The PD valuation models implicitly assume that the entire cash flow generated by the company will eventually be paid out to shareholders, this may happen sooner or later but the accumulated cash (reinvested at the rate of return equal to the applicable cost of capital), will be accounted for at the latest in the residual period.

Other assumptions posited by MM cause the theoretical models to be significantly divergent from what is observed in practice: while postulating zero transactions costs and price taking by the market participants, the assumption of perfect capital markets assures the absolute symmetry of information, which in the case of cash flow retention precludes the management of the company from engaging into negative NPV projects. This, in turn, implies the application of the zero-NPV condition for valuation purposes; the assumption of the rationality of managers and shareholders rules out all the behavioural explanations of the dividend payout, for example, the theory of self-control (Thaler, Shefrin, 1981) or the fluctuation of catering incentives (Baker, Wurgler, 2004). Perfect certainty assumption practically implies the irrelevance of the capital structure for the company's value.

\subsection{Empirical Arguments in Favour of the PD Approach}

Grullon, Michaeli, Swaminathan (2002) conclude that dividend payout policy is connected with the life cycle of a company: as the company is getting mature, it increases dividend payout which is accompanied with a reduction in systematic risk. The authors explain it by the fact that the mature companies are running out of positive NPV projects, which is consistent with the previously discussed theoretical models. Furthermore, Lintner (1956) found that managers were reluctant to announce dividend increase unless they were sure that the 
company was able to maintain the envisaged level of dividend payout in the future. In my opinion, these are characteristics of large mature companies which have an established financial position and are sure not to require the part of cash flow to finance unexpected and potentially attractive investment projects.

Additionally, Benartzi, Michaeli, and Thaler (1997) found a negative correlation between the dynamics of dividend payments and the subsequent change in a company's earnings growth rates, which implies that cash flow retention, may have given the firms an opportunity to engage into positive NPV projects in the future. Implicitly, this suggests that companies tend to use the generated cash flow for investment into attractive investment projects with positive NPV. When the list of positive NPV projects is exhausted, a firm then starts increasing the dividend payout. This may partially explain the positive correlation between the company's size and dividend payout revealed by Redding (1997).

\subsection{Arbitrage Losses Caused by the Omission of the PD}

Velez-Pareja and Magni (2009) state that an investor applying the PD concept in valuation is open to arbitrage losses: the investor contemplating an acquisition of an asset and using the PD approach will come up with a higher value than that yielded by the AD method; if subsequently the investor pays more than the amount produced by the AD approach, the arbitrage loss will occur. Following their line of reasoning, I propose a counter example based on previously presented theoretical assumptions, which proves that the omission of $\mathrm{PD}$ in calculations can potentially result in losses for the investor.

The company owned by a single investor assures the perpetual payment of the actual dividend of 100 under the state of nature 1 and 200 under the state of nature 2. At the same time, investment in the liquid assets which accounts for the PD is 50 under the state of nature 1 and 100 under the state of nature 2 . The states of nature are assumed to be equally probable. Assuming the discount rate of $10 \%$ the valuator applying the $\mathrm{AD}$ approach will come up with the value of $(0.5 \times 100+0.5 \times 200) / 0.1=1,500$, while adding PD to the valuation will yield the result of 2,250. If the potential buyer acquires the company for 1,500 which the owner assumes to be the fair value, and then forces a dividend payout, which is feasible through the management replacement, the acquirer will gain an additional value of 750 without incurring any risks under the assumption of an optimal investment policy being in place. As a result, the initial owner of the company will incur a loss.

\section{Interpretation of PD in Valuation Models}

This section envisages the practical application and interpretation of the PD in the valuation models. Primarily I formulate the assumptions which will underlie the valuation and which obviously deviate from the rigorous assumptions of the theories discussed in the paper. First, I relax the assumption of the optimal investment policy. This implies that two potential 
scenarios are available: the company may have exhausted the list of positive-NPV projects or the company may still envisage some attractive investment opportunities which may require cash flow retention. At the same time, I depart from the assumption of a $100 \%$ payout and assume that the management may formulate the payout policy in a way to maximize the company's value. I assume that the HBU principle applies; meaning that the management is fulfilling fiduciary duty towards shareholders, the corollary being that in the case of failure to deliver the expected results to stockholders the management will be replaced.

I agree with Damodaran (1994) that the availability of positive-NPV projects should be the decisive factor determining payout policy.

If the management envisages a set of attractive investment projects which may enhance the shareholder value, part of the cash flow should be retained. In such a case, the potential dividend will be controlled using the instruments of the liquidity management and afterwards invested into positive-NPV projects, which were previously envisaged by the firm. Assuming that shareholders are indifferent between capital gains and dividend payments and that there is no special tax treatment of either, the value will be maximized (Mielcarz, Paszczyk, 2010). However, if the management is suspected of hubris and inefficient liquidity management, the shareholders should force a dividend payout. In such a case the value is maximized through the $100 \%$ cash flow payout which is consistent with the MM theory.

To summarize, the PD approach must be applied for the purposes of fair value estimation if there is an efficient system of corporate governance and absolute symmetry of information between management and shareholders. Such an approach is endorsed by IFRS 13 and IVS.

\section{The Application of the AD Approach to Valuation}

In certain contexts the above mentioned preconditions of PD application are not fulfilled, prompting the valuator to apply the $\mathrm{AD}$ approach. In particular, I am referring to the assumption of the efficient system of corporate governance in place. Previously, I assumed that the shareholder is treated as a sole proprietor and can claim the entire cash flow generated by the company even if this cash flow is not distributed. If the shareholder has reasonable grounds to suspect that the management of the company is about to invest the retained cash flows into negative-NPV projects, the dividend payout will probably be forced. This implicitly assumes that the shareholders are informed in a timely manner about the investment and payout decisions taken by the management. As stated previously, under such conditions the application of the $\mathrm{PD}$ approach is justified.

However, if the above assumptions are relaxed, the following conditions may arise: 1) there is an information asymmetry between shareholders and management, leaving the investment decisions to the discretion of the latter, which may result in engaging in value-destroying investment enterprises; 2) the stockholders have no efficient legal means of defending their interests (such situations are characteristic for countries with poor law enforcement 
in place, where management replacement is difficult due to conflicts between antagonizing groups of stockholders); 3) the shareholders have no legal means to force a dividend payout if the management is failing to fulfil its fiduciary duty towards the owners. In such a context there are no grounds to assume that shareholders potentially have access to the distributable cash flows, as such decisions remain at the discretions of the managers. What is more, there is a significant moral hazard, since management having the unconstrained influence on the company's financing and investment decisions, might pursue its own interests divergent from the goal of shareholder wealth maximization. This gives reasonable argument to claim that the retained cash will be wasted (for excessive perquisites or negative-NPV projects). The only benefits which the shareholders may contemplate with certainty under such circumstances are the $\mathrm{AD}$, which should constitute the basis for valuation.

Another situation, where the $\mathrm{AD}$ approach is suggested as a technique of accurate value estimation, is the minority interest valuation for private companies. Similarly to the previously discussed situation of poor law enforcement, the minority shareholder may have limited influence on the company's decision making. The financing and investment decisions are shaped by the controlling shareholders, who determine the dividend payout as well. Under such conditions, the minority shareholders cannot force cash flow distribution if they deem the company to have run out of attractive investment opportunities. There is also no active secondary market for the minority shares of private companies, and therefore, the only cash flow which may be anticipated with certainty in such a case is the AD. Incorporating PD into the valuation model of minority interest would erroneously imply unlimited access of the stockholders to the distributable dividend.

The AD approach to valuation clearly has drawbacks. A noted by Damodaran (1994), the actual dividends can exceed available equity cash flows, forcing the company to look for external financing to afford continuous dividend payments. In such cases the company may issue additional stocks or incur more debt to finance the exuberant payout policy. While this clearly has consequences for the company value by means of influencing its capital structure, it may also entail mistakes in equity valuation. However, a valuation based on AD may constitute a conservative estimate of the equity value. This is particularly true for mature companies which, as noted previously, tend to increase dividend payout as the stock of positive-NPV projects is exhausted.

\section{Concluding remarks}

The paper analyzes the concepts of PD and AD along with their application in the valuation models. I conclude that each methodology is applicable under specific circumstances. It is argued that despite being inconsistent with the rigorous theoretical assumptions of MM, the PD methodology is perfectly viable if those assumptions are relaxed, and may constitute a sound solution for fair value estimation. What is more, the omission of PD in valuation may result in the underestimation of the equity value entailing potential losses for the owner 
of the asset. The paper proposes practical recommendation regarding the treatment of PD while formulating the dividend payout policy of the company to avoid value destruction. I also recognize that under specific circumstances (the context of a flawed system of corporate governance or minority interest valuation with no active secondary market for minority shares of private companies) the AD approach appears to be the only available option for accurate valuation.

\section{References}

Baker, M., Wurgler, J. (2004a). Appearing and disappearing dividends: The link to catering incentives. Journal of Financial Economics, 73, 271-288.

Benartzi, S., Michaely, R., Thaler, R.H. (1997). Do changes in dividends signal the future or the past? Journal of Finance, 52 (July), 1007-1034.

Benninga, S.Z., Sarig, O.H. (1997). Corporate Finance. A Valuation Approach. New York, NY: McGraw-Hill.

Black, F. (1976). The dividend puzzle. Journal of Portfolio Management, 2, 5-8.

Damodaran, A. (1994). Damodaran on Valuation. New York: John Wiley.

Damodaran, A. (2006). Valuation approaches and metrics: a survey of the theory and evidence. Available at: http:// www.stern.nyu.edu/ adamodar/pdfiles/papers/valuesurvey.pdf (November). Originally published in Foundations and Trends in Finance, 1 (8), 693-784, 2005.

DeAngelo, H., DeAngelo, L. (2006). The Irrelevance of the MM dividend irrelevance theorem. Journal of Financial Economics, 79, 293-315.

Fernández, P. (2002). Valuation Methods and Shareholder Value Creation. San Diego, CA: Academic Press.

Grullon, G., Michaely, R., Swaminathan, B. (2002). Are Dividend Changes a Sign of Firm Maturity? The Journal of Business, 75 (3), July 2002. Available at: http://ssrn.com/abstract=313843.

Jensen, M., Meckling, W. (1976). Theory of the firm: managerial behavior, agency costs, and ownership structure. Journal of Financial Economics, 3, 305-360.

Jensen, M. (1986). Agency Costs of Free Cash Flow, Corporate Finance, and Takeovers. Am Econ Rev, 76, $323-326$.

Michaud, R., Davis, P. (1981). Valuation Model Bias and the Scale Structure of Dividend Discount Returns. Journal of Finance, 37, 563-573.

Mielcarz, P. (2014). A new approach to private firm fair value valuation in line with IFRS 13 - the concept of the most advantageous market discount (MAMD). BEH - Business and Economic Horizons, 10 (1), 79-85.

Mielcarz, P., Paszczyk, P. (2010). Increasing shareholders value through NPV-negative projects. Contemporary Economics, 4 (3), 119-130.

Mielcarz, P., Wnuczak, P. (2011). DCF fair value valuation, excessive assets and hidden inefficiencies. Contemporary Economics, 44 (4), 44-57.

Miller, M., Modigliani, F. (1961). Dividend Policy, Growth, and the Valuation of Shares. The Journal of Business, 34 (4), 411-433.

Redding, L. (1997). Firm Size and Dividend Payouts. Journal of Financial Intermediation, 6, 224-248.

Thaler, R., Shefrin, H. (1981). An economic theory of self-control. Journal of Political Economy, 89 (2), $392-406$.

Vélez-Pareja, I., Magni, C. (2009). Potential dividends and actual cash flows in equity valuation. A critical analysis. Estudios Gerenciales, 25 (113), 123-150.

\section{FAKTYCZNE I POTENCJALNE DYWIDENDY: TEORIA I PRAKTYKA}

Streszczenie: Koncepcja dywidend potencjalnych (PD) oraz jej zastosowanie w wycenie przedsiębiorstw stanowi źródło polemik w środowisku teoretyków wyceny. Przeciwnicy włączenia PD do wolnych przepływów pieniężnych dla akcjonariuszy wskazują na brak konsystencji logicznej takiego rozwiązania oraz wady teoretyczne tego podejścia, podczas gdy jego zwolennicy dowodzą, że pominięcie PD prowadzi do niedoszacowania wyników wyceny. W mojej opinii, mimo że wykorzystanie PD może budzić wątpliwości 
przy przyjęciu rygorystycznych założeń teorii Modiglianiego-Millera, odstępstwa od założeń teorii MM, obserwowane w praktyce, powodują konieczność uwzględnienia PD w wycenie. Celem artykułu jest przedstawienie kompleksowej analizy ujęcia PD oraz dywidendy faktycznej (AD) w procesie szacowania wartości przedsiębiorstw. Moim zdaniem, każde z podejść może być używane wyłącznie w specyficznych okolicznościach opisanych w artykule. Ponadto w artykule zostały zaprezentowane praktyczne wskazówki odnoście użycia koncepcji faktycznych i potencjalnych dywidend w wycenie.

Słowa kluczowe: faktyczny przepływ pieniężny, dywidendy potencjalne, wolny przepływ pieniężny dla akcjonariuszy, wycena

\section{Citation}

Wnuczak, P. (2017). Actual and Potential Dividends: Reconciling Theory and Practice. Finanse, Rynki Finansowe, Ubezpieczenia, 1 (85), 455-465. DOI: 10.18276/frfu.2017.1.85-36. 